\title{
ANALISIS DAMPAK PEMANFAATAN WAKTU LUANG DI KAMPUS \\ TERHADAP PRESTASI BELAJAR MAHASISWA
}

\author{
Oleh \\ SUHAILI MUNAHAR \\ Email : suhaili.elsa@gmail.com
}

\begin{abstract}
Abstrak
Penelitian ini bertujuan untuk mengetahui pengaruh pemanfaatan waktu luang mahasiswa di kampus terhadap prestasi belajar yang diraih dalam bentuk IP. Tidak bisa dipungkiri bahwa setiap mahasiswa masuk ke kampus menginginkan hasil atau prestasi belajar yang baik sesuai cita-cita, salah sartu indikator keberhasilan belajar ditunjukkan dengan raihan indeks prestasi (IP) yang baik.

Penelitian ini dilakukan di STIT Palapa Nusantara Lombok khususnya mahasiswa Prodi PGMI dengan mengambil seluruh populasi menjadi sampel sebanyak 78 mahasiswa karena kurang dari 100 orang. Desain penelitian yang digunakan berupa Ex post Facto. Pengumpulan data menggunakan teknik tes dalam bentuk angket atau quisioner guna mengumpulkan data pemanfaatan waktu luang mahasiswa di kampus (X) dan dokumentasi berupa daftar KHS IP mahasiswa terkait prestasi belajar (Y).

Hasil penelitian menunjukkan bahwa rata-rata data angket respon berada pada kategori sedang dan prestasi belajar mahasiswa berada pada kategori memuaskan. Pengujian hipotesis menggunakan uji regresi dengan $F_{\text {hitung }}=1,29<F_{\text {tabel }}=3,98$ yang berarti bahwa Ha ditolak dan Ho diterima, yaitu tidak ada pengaruh pemanfaatan waktu luang di kampus terhadap prestasi belajar mahasiswa Prodi PGMI STIT Palapa Nusantara Lombok.
\end{abstract}

Kata kunci : Pemanfaatan waktu luang di kampus, prestasi belajar

\section{PENDAHULUAN}

Tidak bisa dipungkiri setiap mahasiswa masuk kuliah pada suatu Perguruan Tinggi mengiginkan dalam meraih prestasi ditunjukkan dengan Indeks Prestasi (IP), adalah suatu kebanggaan bagi mahasiswa ketika mendapat IP di atas 3,00, bagaimana tidak secara otomatis mahasiswa tersebut mendapat gelar mahasiswa berprestasi sekaligus memberikan kebanggaan tersendiri bagi orang tua dan keluarga. 
Untuk mendapat prestasi yang memuaskan, mahasiswa harus berusaha semaksimalkan mungkin dalam belajar secara serius dan terencana sesuai dengan kompetensi masing-masing. Setiap mahasiswa juga harus meyakini bahkan potensi yang dimiliki merupakan hazanah untuk terus digali dan dikembangkan dalam meraih prestasi yang memuaskan ${ }^{1}$. Tradisi-tradisi intelektual serta aktifitas pokok seperti aktif dalam mengikuti perkuliahan, mengerjakan tugas dengan baik dan tepat waktu serta bertawakkal kepada Tuhan yang Maha Esa adalah syarat untuk meraih prestasi yang dinginkan. Selain aktiftias pokok di atas, setiap mahasiswa juga harus belajar mandiri diluar perkuliahan yang sudah terjadwal, membentuk kelompok diskusi, ke perpustakaan secara terjadwal serta mereview materi yang diberikan di kampus ketika berada di rumah.

Dari hasil pengamatan, pada saat perkuliahan sedang berlansung ketika tidak ada perkuliahan dan ketika pergantian jam kuliah, taman kampua, kantin merupakan tempat yang ramai dikunjungi serta tempat nongkrong paporit mahasiswa daripada mengisi waktu ke perpustakaan atau membaca buku. Tempattempat tersebut hanya dimanfaatkan untuk ngobrol, bersendau gurau dan aktifitas yang kurang bermanfaat, jarang mahasiswa menggunakan waktu tersebut untuk diskusi materi perkuliahan dan belajar mandiri, ada juga mahasiswa yang acuh dengan lingkungannya karena sibuk membuka smartpone yang mereka miliki sehingga tidak tertarik untuk membuka buku. Hal tersebut menunjukkan bahwa penggunaan waktu luang oleh mahasiswa Program Studi Pendidikan Guru Madrasah Ibtidaiyah (PGMI) STIT Palapa Nusantara Lombok waktu belajar belum efektif.

Berdasarkan hasil wawancara dengan sejumlah mahasiswa, didapatkan informasi bahwa sebagian besar mahasiswa jarang memanfaatkan waktu luangnya untuk belajar mandiri selama berada di Kampus. Sedangkan persentase mahasiswa yang menggunakan waktu luang untuk belajar sangatlah kecil. Waktu luang yang memiliki mahasiswa lebih banyak digunakan untuk bermain-main atau sibuk membuka media sosial melalui smartpone yang dimiliki. Mereka juga

\footnotetext{
${ }^{1}$ Lakein, Alan. (2003). Waktu dan Sukses : bagaimana memanfaatkan waktu secara efektif hal 56
} 
menyakatan pemanfaatan smartpone juga jarang digunakan sebagai refrensi atau bahan bacaan materi-materi kuliah, namun lebih tertarik membuka game dan media sosial yang mereka miliki.

Ada juga sebagian mahasiswa yang memanfaatkan waktu luang untuk aktiftias non akademis seperti kegiatan-kegiatan organisasi baik intra maupun ekstra kampus yang terkadang berlebihan sehingga waktu jam kuliah ditinggalkan walaupun memang disadari bahwa fungsi serta peran mahasiswa sesungguhnya bangsa sangat besar sebagai harapan masyarakat dan penerus estapet perjuangan bangsa tetapi terkadang berlebihan dengan mengorbankan aktifitas akademis.

Dari hasil keterangan dari beberapa mahasiswa didapat digolongkan menjadi dua tipe, 1) tipe mahasiswa yang memiliki Indeks Prestasi (IP) di atas 3 cenderung memanfaatkan waktu luang dengan membaca baik diperpustakaan atau membuka refrensi di internet, 2) mahasiswa yang memiliki IP sedang dan rendah cenderung meluangkan waktu dengan bersendau gurau dan sibuk membuka smartpone mereka dengan media sosial dan game. Hal ini didukung oleh Lakein dalam bukunya "penggunaan waktu secara efektif dapat meningkatkan prestasi".

\section{METODE PENELITIAN}

Jenis penelitian ini menggunakan "ex post facto"merupakan penelitian ex post facto adalah penelitian secara empiris dan sistematis dimana peneliti tidak mempunyai kontrol lansung terhadap variabel bebas karena fenomena telah terjadi $^{2}$. Data tentang pemanfaatan waktu luang mahasiswa di kampus kemudian dari dara tersebut dicari pengaruhnya terhadap prestasi belajar berupa IPK mahasiswa Program Studi PGMI STIT palapa Nusantara Lombok.

\section{Instrumen Penelitian}

Intrumen yang digunakan dalam penelitian ini terdiri dari dua alat yaitu :

\section{Angket}

Angket dibuat untuk memperoleh data tentang pemanfaatan waktu luang mahasiswa Program Studi PGMI STIT Palapa Nusantara Lombok. Angket digunakan adalah angket tertutup yang berbentuk skala bertingkat dengan empat

${ }^{2}$ Nyoman Dantes Prof.Dr.(2012) Metode Penelitian hal. 124 
pilihan jawaban yaitu A (selalu) dengan nilai 4, B (sering) dengan nilai 3, C (kadang-kadang) dengan nilai 2, dan D (tidak pernah) dengan nilai 1. Angket ini juga disertai dengan pernyataan negatif dengan nilai terbalik dengan pertanyaan positif. Angket yang telah dibuat diuji dengan validitas dan realibilitas.

\section{Validitas}

Untuk interpretasi terhadap besarnya koefisien korelasi, harga r-hitung dikonsultasikan dengan harga $r$-tabel dengan taraf kesalahan 5\%. Jika harga $r$ hitung yang diperoleh lebih besar dari $r$ - tabel maka butir soal tersebut dikatakan valid, namun jika harga $r$-hitung yang diperoleh lebih kecil dari $r$-tabel maka butir soal tersebut direvisi atau dibuang.

\section{Realibilitas}

Instrumen yang reliabel adalah instrumen yang dapat digunakan oleh siapa saja, kapan saja, dan dimana saja. Untuk menentukan koefisien reliabilitas tes digunakan rumus formula Kuder-Richadson -21 atau KR $21^{3}$.

Berdasarkan interpretasi tersebut, dalam penelitian ini butir tes dikatakan baik jika koefisisen reliabilitasnya minimal dalam kategori sedang. Dengan demikian butir-butir tes yang memiliki koefisien reliabilitas di bawah kategori sedang akan direvisi

\section{Dokumentasi}

Dokumentasi dalam penelitian ini adalah hasil belajar mahasiswa Prodi PGMI STIT Palapa Nusantara Lombok tahun akademik 2015/2016 yang ditunjukkan IPK terakhir yang diperoleh mahasiswa.

\section{Teknik Analisis Data}

Teknik analisis data yang digunakan dalam penelitian ini adalah :

\section{Analisis Statistik Deskriptif}

a. Penyajian data dalam bentuk tabel kategorisasi

b. Menentukan nila rata-rata.

c. Menentukan standar deviasi atau simpangan baku.

\footnotetext{
${ }^{3}$ Candiasa, (2011) statistic deskriptif kuantitatif hal. 56
} 
d. Menentukan kategori pemanfaatan waktu luang mahasiswa di Kampus dan prestasi Belajar mahasiswa.

Untuk menentukan tingkat efektifitas pemanfaatan waktu luang mahasiswa ditentukan dengan mengkonversikan nilai rata-rata pemnfaatan waktu lunag mahaiswa di kampus dalam pedoman konversi norma absolut skala tiga.

Untuk kategori prestasi belajar mahasiswa sesuai IPK yang diraih berdasarkan KHS semester genap.

\section{Analisis inferensial}

a. Uji Normalitas Data $\left(x^{2}\right)$

$f_{0}$ adalah frekuensi yang diperoleh berdasarkan data atau frekuensi hasil sedangkan $f_{h}$ adalah frekuensi yang diharapkan dengan kriteria apabila $x^{2}{ }_{\text {hitung }}$ $<x_{\text {tabel }}^{2}$ dengan derajat kebebasan $(\mathrm{dk})=\mathrm{k}-1$ maka data berdistribusi normal pada taraf signifikansi $5 \%$.

b. Analisis Regresi

\section{Regresi Linier Sederhana}

Regresi linier sederhana digunakan untuk mengetahui bentuk hubungan antara pengaruh pemanfaatan waktu luang mahasiswa di kampus terhadap prestasi belajar mahasiswa Prodi PGMI STIT Palapa Nusantara Lombok dengan rumus :

$$
\begin{aligned}
& \hat{y}=a+b x \\
& \mathrm{Y}=\text { Prestasi belajar mahasiswa } \\
& \mathrm{X}=\text { pemanfaatan waktu luang }
\end{aligned}
$$

Uji keberartian Garis Regresi

Uji keberartian Garis Regresi diuji menggunakan uji F untuk mengetahui dapat tidaknya variabel bebas mempengaruhi variabel terikat Merumuskan hipotesis

Ho $: \mathrm{b}=0$, koefisien arah regresi tidak berarti, artinya tidak ada pengaruh antara pemanfaatan waktu luang di kampus terhadap prestasi belajar $\mathrm{H} a: \mathrm{b} \neq 0$, koefisien arah regresi berarti, artinya ada pengaruh antara pemanfaatan waktu luang di kampus terhadap prestasi belajar. 


\section{HASIL PENELITIAN DAN PEMBAHASAN}

Dalam penelitian ini diketahui tingkat intensitas pemanfaatan waktu luang mahasiswa STIT Palapa Nusantara di kampus secara umum tergolong sedang. Dengan perincian 7 orang mahasiswa $(8,97 \%)$ kategori tinggi, 41 orang $(52,66 \%)$ kategori sedang, dan 30 orang kategori rendah (38,37\%).

Sedangkan untuk hasil belajar yang dicapai mahasiswa STIT Palapa Nusantara Prodi PGMI sebagian besar predikat memuaskan 26, 92\% dan sangat memuaskan 62,17\%. Dengan besarnya persentase jumlah mahasiswa yang memiliki IPK dengan predikat memuaskan dan tidak memuaskan berarti bahwa usaha meningkatkan hasil belajar mahasiswa perlu ditingkatkan dengan mengoptomalkan pemanfaatan waktu luang yang ada dengan baik dan sistematis selama berada di kampus maupun di rumah untuk kegiatan belajar mandiri.

Untuk uji keberartian regresi atau uji hipotesis didapatkan $F_{\text {hitung }}=$ $1,29<F_{\text {tabel }}=3,98$, ini menunjukkan bahwa hipotesis Ha ditolak. Artinya, pemanfaatan waktu luang mahasiswa di kampus tidak berpengaruh terhadap prestasi belajar mahasiswa Prodi PGMI STIT Palapa Nusantara Lombok.

Tidak adanya pengaruh antara pemanfaatan waktu luang mahasiswa di kampus terhadap prestasi belajar juga dijelaskan melalui persamaan garis regresi yang diperoleh. Persamaan garis regresi yang diperoleh antara pemanfaatan waktu luang mahasiswa di kampus terhadap prestasi belajar, persamaan tersebut menunjukkan bahwa, setiap penambahan satu unit pemanfaatan waktu luang mahasiswa di kampus (X) maka prestasi belajar mahasiswa (Y) akan bertambah sebesar 0,424 atau sebesar 4,24\%. Penambahan satu unit pemanfaatan waktu luang mahasiswa di kampus yang menghasilkan penambahan prestasi belajar sebesar 4,24\% merupakan angka yang kecil sehingga dinaggap tidak berarti, artinya, tidak ada pengaruh pemanfaatan waktu luang di kampus (X) terhadap hasil belajar mahasiwa (Y).

Tidak adanya pengaruh antara pemanfaatan waktu luang mahasiswa di kampus dengan prestasi belajar yang diraih mahasiswa ini juga dapat disebabkan oleh beberapa faktor. Beberapa dinataranya yaitu mahasiswa Prodi PGMI belum menggunakan waktu luangnya di kampus untuk kegiatan belajar secara optimal, 
hal ini disebabkan oleh jadwal serta ruangan yang tidak tentu dan Dosen banyak yang tidak masuk mengisi jam kuliah. Selain itu, jika dilihat dari data hasil angket pemanfaatan waktu luang dengan pertanyaan positif, mahasiswa lebih banyuak mennjawab dengan jawaban kadang-kadang dan tidak pernah. Begitu pula sebaliknya untuk butir angket dengan pertanyaan negative mahasiswa lebih banyak menjawab dengan jawaban sering. Hal ini menandakan bahwa mahasiswa belum memanfaatkan waktu luangnya secara optimal selama berada di kampus.

Faktor berikutnya yang menyebabkan tidak adanya pengaruh pemanfaatan waktu luang di kampus terhadap prestasi belajar adalah adanya aspek dalam pemanfaatan waktu luang yang tidak memberikan kontribusi dalam peningkatan prestasi belajar. Hal ini didukung oleh penelitian Rostinah dalam skripsinya yang menemukan bahwa tidak ada pengaruh pemanfaatan sumber belajar oleh mahasiswa terhadap prestasi belajar yang diraih mahasiswa. Sumber belajar yang dimaksud adalah perpustakaan, dosen, pasilitas internet yang ada. Hal ini ditandai dengan rendahnya skor jawaban angket pemanfaatan waktu luang pada butir 4 dan 6 yang mengungkapkan tentang kurangnya penggunaan perpustakaan oleh mahasiswa sebagai sarana belajar dalam mengisi waktu luang. Berdasarkan observasi, tidak banyak buku-buku yang relevan dengan kebutuhan mahasiwa Prodi PGMI terutama yang ada disilabus dan buku pegangan dosen sulit ditemukan. Selain kurangnya pemanfaatan waktu luang terhadap prestasi belajar juga dapat dilihat dari hasil jawaban angket pada butir nomor 3 dan 20 tentang pemanfaatan dosen dan teman untuk diskusi terkait materi yang belum dipahami dan pemanfaatan internet juga memiliki skor jawaban yang rendah disebabkan oleh pemanfaatan pasilitas internet digunakan untuk membuka sosial media dan youtube.

Faktor lain yang juga menyebabkan tidak adanya pengaruh pemanfaatan waktu luang terhadap prestasi belajar yang diraih mahasiswa karena sempitnya waktu luang yang dimiliki di kampus, mahasiswa jarang menggunakan waktu luang untuk belajar dan berdiskusi, lebih banyak digunakan untuk mengobrol halhal yang tidak berkaitan dengan materi perkuliahan. Sebagaimana diketahui juga bahwa, waktu luang mahasiswa di kampus merupakan salah satu bagian kecil dari 
keseluruhan waktu yang dimiliki. Selain di kampus, mahasiswa memiliki banyak waktu luang saat berada di rumah karena masuk kuliah dari jam 14.00 - 17.30 wita. Berdasarkan hasil wawancara juga dari sampel bahwa mahasiswa lebih banyak menggunakan waktu luang di rumah untuk belajar daripada di kampus dengan alasan lebih konsentrasi karena suasana rumah lebih tenang dibandingkan belajar di kampus dengan suasana yang cukup bising dan rebut.

Faktor lain yang juga menyebabkan hipotesis ditolak adalah ada sejumlah mahasiswa yang memiliki skor pemanfaatan waktu luang di kampus rendah tapi memiliki IPK tinggi dan sebaliknya, ada mahasiswa yang memiliki skor pemanfaatan waktu luang tinggi tetapi IPK rendah. Jal ini menunjukkan bahwa prestasi belajar yang diraih tidak semata-mata dipengaruhi oleh pemanfaatan waktu luang di kampus tetapi ada faktor lain yang mempengaruhi prestasi belajarnya. Berhasil atau tidaknya seseorang dalam mencapai prestasi belajar yang baik selain faktor internal seperti tingkat IQ, kondisi fsikologi juga mempengaruhi faktor eksternal seperti kondisi keluarga, lingkungan masyarakat, pergaulan dll. Hal ini sesuai dengan pendapat Slameto $^{4}$ dalam bukunya menyatakan bahwa dalam situasi yang sama, mahasiswa mempunyai tingkat intelegensia yang tinggi akan memiliki prestasi belajar yang baik daripada mahasiswa yang memiliki intelegensia rendah. Emotional Quotient (EQ) juga berpengaruh terhadap prestasi belajar. Selain itu faktor yang mempengaruhi adalah bakat dan minat seseorang dalam belajar.

Dari uraian di atas terlihat bahwa, pemanfaatan waktu luang mahasiswa Prodi PGMI STIT Palapa nusantara Tahun akademik 2017/2018 di kampus belum optimal sehingga tidka memberikan kontribusi positif terhadap prestasi belajar yang diraih. Bukan hal yang negative, akan tetapi mahasiswa Program Studi PGMI STIT Palapa Nusantara TA 2017/2018 juga cenderung lebih banyak memanfaatkan waktunya saat berada dirumah atau ditempat lain diluar kampus untuk belajar yang lebih efektif.

\footnotetext{
${ }^{4}$ Slameto.2003. Belajar dan faktor-faktor yang mempengaruhinya. Jakarta : Rineka Cipta. h. 56
} 


\section{SIMPULAN DAN SARAN}

\section{Simpulan}

Berdasarkan hasil penelitian dan pembahasan di atas, dapat disimpulkan beberapa hal diantaranya,

1. Tingkat intensitas pemanfaatan waktu luang mahasiwa Program Studi PGMI TA 2017/2018 tergolong kategori sedang.

2. Prestasi belajar mahasiwa Program Studi PGMI sebagian besar termasuk dalam predikat memuaskan.

3. Tidak terdapat pengaruh pemanfaatan waktu luang mahasiswa di kampus terhadap prestasi belajar yang diraih mahasiswa program studi PGMI tahun akademik 2017/2018.

\section{Saran}

Dari keseluruhan hasil penemuan yang diperoleh oleh peneliti berharap perbaikan dari semua elemen yang ada di kampus, baik dosen, mahasiswa maupun stake kholder yang ada dengan upaya-upaya yang konstruktif. Dari beberapa faktor penyebab kurangnya pemanfaatan waktu luang di kampus, perlu adanya evaluasi terutama tentang;

1. Peneliti berharap kepada dosen untuk intens berinteraksi, membimbing dan mengarahkan mahasiswa untuk memanfaatkan waktu dengan sebaik-baiknya untuk belajar dan memberikan tugas kepada mahasiswa disaat ada waktu luang dan ketika tidak masuk kuliah.

2. Kelengkapan pasilitas pendukung terutama perpustakaan di Kampus perlu ditingkatkan agar menjadi sumber belajar baik bagi dosen maupun mahasiswa dalam mengisi waktu luang di kampus.

3. Bagi mahasiwa, diharapkan menjadi sumber belejar dalam meningkatkan kesadaran tentang pemanfaatan waktu luang dengan sebaik-baiknya guna meraih cita-cita dan demi pengabdian kepada masyarakat, gama, dan bangsa.

4. Karena tidak ada pengaruh pengaruh pemanfaatan waktu luang mahasiswa di kampus terhadap prestasi belajar yang diraih, disarnkan untuk adanya 
penelitian selanjutnya untuk meneliti kembali masalah pemanfaatan waktu luang mahasiswa dengan ruang lingkup yang lebih luas.

\section{DAFTAR PUSTAKA}

Anonim, 1982/1983. Analisis Pendidikan Tahun III No. 4, Hendayat Soetopo :

Pendayagunaan waktu luang di Kampus. Depdikbud

Arikunto Suharsimi. 1997. Prosedur Penelitian Suatu Pendekatan Praktek.

Jakarta : PT Rineka Cipta

Baharudddin, M. PdI.2010. Psikologi Pendidikan. Yogyakarta : Ar-Ruzz Media

Djamarah, Syaipul Bahri. 2000. Rahasia Sukses Belajar. Jakarta : Rineka Cipta

Gie, The Liang. 1995. Cara Belajar yang Efisien jilid II. Yogyakarta : Liberty

Lakein, Alan. 2003. Waktu dan Sukses : bagaimana memanfaatkan waktu secara efektif. Semarang : Dahara Prize.

Muhajirin. 2003. Hubungan kegiatan belajar di luar jam kuliah dengan prestasi belajar mahasiswa pendidikan kimia FKIP Universitas Mataram (Skripsi). FKIP Universitas Mataram

Nasution. Dan Mursel, J. 2002. Mengajar Dengan Sukses. Jakarta : Bumi Aksara.

Nyoman Dantes Prof.Dr. 2012. Metode Penelitian. Yogyakarta : Andi

Rianto, Yatim. 1996. Metodologi Penelitian Pendidikan. Surabaya : SIC

Slameto.2003. Belajar dan faktor-faktor yang mempengaruhinya. Jakarta : Rineka Cipta.

Sudjana Prof. Dr. 1996. Metode Statistika. Bandung : Tarsito

Sugiyono, Prof. Dr. 2010. Statistik Nonparametris untuk penelitian. Bandung :

Alfabeta 